\title{
The Microbial Oxidation of Methanol
}

\section{ISOLATION AND PROPERTIES OF PSEUDOMONAS SP. M 27}

\author{
By C. ANTHONY AND L. J. ZATMAN \\ Department of Microbiology, University of Reading
}

\section{(Received 21 November 1963)}

Several bacteria are known which are capable of growth with methanol or certain other $\mathrm{C}_{1}$ compounds as sole source of carbon and energy (Peel \& Quayle, 1961), but little is known about the enzymes involved in the oxidation of methanol (Quayle, 1961). It has been suggested (Dworkin \& Foster, 1956; Leadbetter \& Foster, 1958; Harring. ton \& Kallio, 1960; Kaneda \& Roxburgh, $1959 b$ ) that methanol oxidation proceeds as follows:

$$
\mathrm{CH}_{3} \cdot \mathrm{OH} \rightarrow \mathrm{H} \cdot \mathrm{CHO} \rightarrow \mathrm{H} \cdot \mathrm{CO}_{2} \mathrm{H} \rightarrow \mathrm{CO}_{2}+\mathrm{H}_{2} \mathrm{O}
$$

Methanol is assimilated by Pseudomonas AM 1 as a substance at the oxidation level of formaldehyde but no enzyme for the oxidation of methanol to this level was found in this organism by Large \& Quayle (1963). The present paper describes the isolation and properties of a pseudomonad, Pseudomonas sp. $M$ 27, which is capable of growth with methanol as sole source of carbon and energy; experiments on the metabolism of methanol by washed suspensions of this organism are also described. A preliminary report of this work has been published (Anthony \& Zatman, 1963).

\section{METHODS}

Isolation and growth media. The basal medium used had this composition $(\%, w / v):\left(\mathrm{NH}_{4}\right)_{2} \mathrm{SO}_{4}, 0 \cdot 2 ; \mathrm{NaCl}, 0.05$; $\mathrm{MgSO}_{4}, 7 \mathrm{H}_{2} \mathrm{O}, 0.0025 ; \mathrm{FeSO}_{4}, 7 \mathrm{H}_{2} \mathrm{O}, 0.0001 ; \mathrm{KH}_{2} \mathrm{PO}_{4}, 0.2$ (dissolved separately), was added and the mixture adjusted to $\mathrm{pH} 6 \cdot 8-7 \cdot 1$ with $\mathrm{NaOH}$ and autoclaved at $121^{\circ}$ for $20 \mathrm{~min}$. To this basal medium was added methanol (to $0.4 \%, w / v$ ) or other carbon and energy source (to $0.2 \%$, $\mathbf{w} / \mathbf{v}$. Solutions of carbon sources were neutralized, when necessary, and sterilized by filtration through sintered glass before addition to the basal medium. A solid medium was prepared by adding $1.5 \%$ of agar (Oxoid) to the basal medium, methanol or formate being added after cooling the melted medium to $45^{\circ}$ just before pouring plates. To test the ability to grow with various compounds as sole carbon and energy source, a straight-wire inoculum from a $72 \mathrm{hr}$. culture in liquid methanol medium was used and three further subcultures were made where necessary. All cultures were incubated at $30^{\circ}$.

Purification of organisms. The organisms isolated were purified by alternate streaking on methanol- (or formate-) agar and picking single colonies into liquid methanol (or formate) medium; the two processes were each repeated at least five times.

Preparation of washed suspensions of organism M 27. Large quantities of organisms for metabolic studies were obtained by growing organism M 27 in shaken 1 l. conical flasks, each containing $300 \mathrm{ml}$. of basal medium and methanol $(0.4 \%, w / v)$ or sodium lactate $(0.2 \%, w / v)$. Slight clumping of the organisms occurred during growth under these conditions and the growth curve was obtained by determining the dry wt. of washed organisms $/ \mathrm{ml}$. of culture at suitable intervals of time after inoculation. Before use as an inoculum (usually $5 \%$ by vol. of a culture of exponentialphase organisms) the organisms were subcultured four times in the growth medium to be used. The flasks of inoculated medium were incubated at $30^{\circ}$ on a gyratory shaker, harvested by centrifugation when in the exponential phase of growth, washed twice in $0.05 \mathrm{M}$-phosphate buffer, pH 7.0, and finally suspended and stored in this buffer at $2^{\circ}$. When grown regularly with methanol under these conditions the organisms were harvested $36-48 \mathrm{hr}$. after inoculation.

Buffer solutions. Buffer solutions were prepared according to the data of Dawson, Elliott, Elliott \& Jones (1959). Phosphate buffer (0.05 $\mathrm{M})$ was used for the range $\mathrm{pH} \mathrm{5 \cdot 6-7 \cdot 6}$ and tris- $\mathrm{HCl}(0.05 \mathrm{M})$ for the range $\mathrm{pH} 6 \cdot 9-9 \cdot 2$.

Manometric experiments. Oxygen uptake or evolution of $\mathrm{O}_{2}$ (in the presence of $\mathrm{H}_{2} \mathrm{O}_{2}$ ) by washed organisms was measured by conventional manometric techniques at $30^{\circ}$, with air as gas phase (Umbreit, Burris \& Stauffer, 1957). Unless otherwise stated the main compartment of each vessel contained $0.05 \mathrm{M}$-phosphate buffer, $\mathrm{pH} 7.0$, washed organisms equivalent to 2-8 mg. dry wt., and inhibitor when required; substrate was added from the side arm; total volume, $3.0 \mathrm{ml}$. The centre well contained $0.2 \mathrm{ml}$. of $10 \%(w / v) \mathrm{KOH}$ and a filter-paper wick (for $\mathrm{CO}_{2}$ absorption); this was replaced by $0.2 \mathrm{ml}$. of $10 \%$ (w/v) KCN-10\% $(\mathrm{w} / \mathrm{v}) \mathrm{KOH}(10: 1, \mathrm{v} / \mathrm{v})$ in experiments involving cyanide. Initial rates of uptake or evolution of $\mathrm{O}_{2}$ are expressed as $Q_{\mathrm{O}_{2}}$ values ( $\mu \mathrm{l}$. of $\mathrm{O}_{2} / \mathrm{mg}$. dry wt./hr.). Unless otherwise stated sufficient substrate was used in all experiments to give the maximum initial rate as measured at $\mathrm{pH} 7 \cdot 0$.

Inhibitors. Organisms were always incubated with the inhibitor in the reaction mixture at $30^{\circ}$ for at least $20 \mathrm{~min}$. before substrate addition and measurement of uptake or evolution of $\mathrm{O}_{2}$.

Spectrophotometry. All spectrophotometric measurements were made with a Unicam SP. 500 spectrophotometer with $3 \mathrm{ml}$. cuvettes of light-path $10 \mathrm{~mm}$. For determinations of absorption spectra the extinction was measured at wavelength increments of $5 \mathrm{~m} \mu$, or of $2 \mathrm{~m} \mu$ in the region of maxima or minima.

Measurement of catalase. The catalase activity of washed suspensions of methanol-grown organism M 27 was estimated manometrically by following the rate of production of $\mathrm{O}_{2}$ in the presence of $0 \cdot 12 \mathrm{M}-\mathrm{H}_{2} \mathrm{O}_{2}$. The Warburg vessels contained $0.05 \mathrm{M}$-phosphate buffer, $\mathrm{pH} 7.0$, and washed organisms, $0.43 \mathrm{mg}$. dry wt. equiv.; $\mathrm{H}_{2} \mathrm{O}_{2}$ was added from the side arm; 
total volume, $3.0 \mathrm{ml}$; gas phase, air; temperature, $30^{\circ}$. In the presence of a potent catalase inhibitor $4.3 \mathrm{mg}$. dry wt. equiv. of organisms/vessel could be used; this larger amount was used for concurrent determination of methanol oxidation by uptake of $\mathrm{O}_{2}$.

Formaldehyde estimation. Formaldehyde was estimated by the chromotropic acid reaction (MacFadyen, 1945). Chromotropic acid (formaldehyde reagent grade, sodium salt) was obtained from British Drug Houses Ltd. and AnalaR formaldehyde solution from Hopkin and Williams Ltd. The formaldehyde was standardized by oxidation with excess of standard alkaline iodine solution, the excess of iodine being back-titrated with standard sodium thiosulphate solution (Treadwell \& Hall, 1935). A standard curve for the chromotropic acid assay of formaldehyde was made from the values obtained with the standard formaldehyde solution.

Formaldehyde accumulation during methanol oxidation. Lactate-grown organisms (4 mg. dry wt. equiv.) were incubated in Warburg vessels at $30^{\circ}$ with methanol (5 or $10 \mu$ moles $)$ and semicarbazide $(100 \mu$ moles $)$ in $0.05 \mathrm{~m}$ phosphate buffer, pH 7.0; total volume, 3.0 ml.; centre wells, $0.2 \mathrm{ml}$. of $10 \%(\mathrm{w} / \mathrm{v}) \mathrm{KOH}$ and filter-paper wick. The incubations were continued until the rate of uptake of $\mathrm{O}_{2}$ had decreased to the endogenous rate. A portion of the incubation mixture was then added to the chromotropic acid reagent for determination of trapped formaldehyde. All the results quoted have been corrected for any material present in the organisms which gave a positive reaction with the chromotropic acid reagent in the absence of methanol. At zero time a mixture of organisms and methanol contained no more formaldehyde than organisms alone.

\section{RESULTS}

Organisms isolated. Organism M 27 was obtained from a suspension of garden soil (Slough, Bucks.) streaked on methanol-agar and purified as described in the Methods section. Eight other organisms were isolated in a similar fashion from other garden soils (three on formate-agar). These were similar to organism M 27 in all characters examined, but they were not tested on the complete range of carbon and energy sources used with organism M 27.

Morphological studies. All organisms were Gramnegative straight rods, $0 \cdot 8 \mu \times \mathbf{2} \cdot 6 \mu$, motile by single polar flagella (stained by the method of Rhodes, 1958). When stained by Gram's method one to three non-staining vacuoles were seen. Burdon's (1946) fat stain showed that the unstained areas were sudanophilic.

Growth characters. Colonies of all organisms were pink (on methanol-agar) or red (on nutrient-agar), circular, convex or flat, shiny, with an entire edge. After incubation at $30^{\circ}$ for 3 days colonies were punctiform and after 7 days were about $1 \mathrm{~mm}$. in diameter. Growth almost as good was obtained on methanol-agar as on nutrient (Evans peptone + Lab Lemco)-agar. The pigment was not soluble in water and was always seen when growth occurred. All organisms grew in nutrient broth; they were all strict aerobes and were catalase-positive whether grown on defined or complex media.

Growth in chemically defined media. All organisms grew in serial subculture in liquid methanol medium without added growth factors. All grew well with methanol, formate, ethanol, oxalate, acetate or lactate as carbon and energy source; poor growth occurred with citrate, propionate, propan-1-ol, glucose or sucrose, and in Koser's citrate medium. Neither serine nor formaldehyde served as sole carbon and energy source. No growth occurred in the defined basal medium when incubated in methane-air $(1: 1, v / v)$. (The methane used was obtained in cylinders from Mogden Purification Works, Isleworth, Middlesex.) Organism M 27 also grew well with methylamine, succinate, malate or fumarate, but no growth occurred with formamide, dimethylamine, glycollate or glycine as sole carbon and energy source.

\section{Pigment of organism $M 27$}

Purification of the pigment was not attempted but the absorption spectra of crude extracts of methanol-grown organisms were determined and compared with those obtained by other workers who used organisms similar to organism M 27. The solvent was that in which the pigment was extracted and the spectra were measured against a water blank.

Chloroform extract. Centrifuged organisms were dried at $55^{\circ}$ for $24 \mathrm{hr}$. and extracted with chloroform at room temperature; the pigment was slowly soluble. The absorption spectrum obtained was similar to that observed by Harrington \& Kallio (1960) with a chloroform extract of the Iowa strain of Pseudomonas methanica; both have an absorption peak at $507 \mathrm{~m} \mu$.

Methanol extract. Centrifuged organisms were extracted with methanol at room temperature. The spectrum of this extract, with absorption peaks at 490 and $520 \mathrm{~m} \mu$, was similar to the spectrum obtained by Leadbetter \& Foster (1958) with a methanol extract of Pseudomonas methanica. Kaneda \& Roxburgh (1959a) extracted a freezedried suspension of Pseudomonas sp. PRL-W 4 with cold ethanol and purified the extract by chromatography on silicic acid; absorption maxima for the eluted material occurred at 455, 488 and $520 \mathrm{~m} \mu$.

Chloroform-methanol extract. Centrifuged organisms were extracted with chloroform-methanol $(1: 1, v / v)$ at room temperature; the spectrum of the extract showed peaks at $315,476,499$ and $526 \mathrm{~m} \mu$. Peel \& Quayle (1961) extracted the pigments from Pseudomonas AM 1 in a similar way, and purified the extract on a column of silicic acid. The spectrum of each of the ten separate bands had peaks at 270 , $315,388,472,497$ and $526 \mathrm{~m} \mu$; the extract from organism M 27 gave a similar curve. 
The properties of the pigment of organism M 27 correspond to those of highly unsaturated carotenoids (Karrer \& Jucker, 1950).

\section{Oxidation of various substrates by washed suspensions of organism $M 27$}

The results recorded in Table 1 show that enzymes catalysing the oxidation of methanol, formaldehyde and formate, as well as ethanol, lactate and glyoxylate, were present in methanol-grown and lactategrown organisms, i.e. they appear to be constitutive enzymes.

The total oxygen consumption by methanolgrown organisms in the presence of methanol, formaldehyde or formate was 60, 90 and $50 \%$ respectively of the amount required for complete oxidation of substrate to $\mathrm{CO}_{2}$ and water. The presence of $1 \mathrm{~mm}-2,4$-dinitrophenol had no effect on these values.

The pH optima (with lactate-grown organisms) were $6 \cdot 5-7 \cdot 5$ for methanol oxidation, $6 \cdot 5-7 \cdot 0$ for formaldehyde oxidation and about $6 \cdot 0$ for formate oxidation.

\section{Effect of various substances on the oxidative metabolism of organism $M 27$}

Cyanide. With methanol-grown organisms the rate of oxidation of endogenous substrate was inhibited $50 \%$ by $1 \mathrm{~mm}$-potassium cyanide whereas the oxidation of methanol, ethanol, formaldehyde, formate or lactate was completely inhibited. This suggests that cyanide inhibits some common factor essential for the aerobic oxidation of each of these substrates, e.g. cytochrome oxidase.

\section{Table 1. Oxidative behaviour of organism $M 27$ grown on methanol and on lactate}

$Q_{\mathrm{O}_{2}}$ values with various substrates have been corrected for endogenous oxygen uptake. The values for methanolgrown organisms are mean values obtained with many batches of organisms; those for lactate-grown organisms are from one batch only. Gas phase, air; temp., $30^{\circ}$; centre well, $0.2 \mathrm{ml}$. of $10 \%(\mathrm{w} / \mathrm{v}) \mathrm{KOH}$; main compartment, $4 \mathrm{mg}$. dry wt. equiv. of organism and $0.05 \mathrm{M}$-phosphate buffer, $\mathrm{pH}$ 7.0; side arm, substrate; total volume, $3 \mathrm{ml}$.

$\begin{array}{lrr}\begin{array}{l}\text { Growth substrate } \ldots . . . \\ \text { Substrate for oxidation } \\ \text { ( } \mu \text { moles/3 ml.) }\end{array} & & \text { Methanol } \\ \text { None } & 11 & \\ \text { Methanol (10) } & 102 & 11 \\ \text { Ethanol (20) } & 89 & 150 \\ \text { Formaldehyde (20) } & 145 & 112 \\ \text { Formate (160) } & 57 & 170 \\ \text { Lactate (16) } & 21 & 117 \\ \text { Glyoxylate (10) } & 8 & 27 \\ \text { Serine (16) } & 0 & 15 \\ & & 0\end{array}$

Sodium hypophosphite. Formate oxidation by a number of bacteria is inhibited by sodium hypophosphite (Takamiya, 1942, 1943, 1953; Campbell, 1954; Bachrach, 1957; Kornberg \& Sadler, 1960; Peel \& Quayle, 1961). Although 2 mm-hypophosphite had no effect on the rate of oxidation of ethanol, lactate or endogenous substrate by lactategrown organism $M 27$, the rates of oxidation of formate, formaldehyde and methanol were inhibited 83,29 and $27 \%$ respectively. These results suggest that formate is an intermediate in the oxidative metabolism of methanol and formaldehyde by organism M 27.

Chelating agents. Harrington \& Kallio (1960) showed that methanol oxidation by Pseudomonas methanica (Iowa strain) was inhibited virtually $100 \%$ by 5 mM-EDTA and by $1 \mathrm{~mm}-\alpha \alpha^{\prime}$-bipyridyl. With methanol-grown organism M 27, methanol oxidation was completely inhibited by $0.1 \mathrm{~mm}$ EDTA and ethanol oxidation by $5 \mathrm{~mm}$-EDTA, but $10 \mathrm{~mm}-\alpha \alpha^{\prime}$-bipyridyl had a negligible effect. The oxidation of formaldehyde, formate, lactate or glyoxylate by organism M 27 was not inhibited by 5 mM-EDTA. Investigation of the relief of the EDTA inhibition by $0 \cdot 1 \mathrm{M}-\mathrm{Fe}^{2+}$ ions (as $\mathrm{FeSO}_{4}$ ), as claimed by Harrington \& Kallio (1960), showed that this apparent relief was due to an artifact caused by the aerobic chemical oxidation of $\mathrm{Fe}^{2+}$ to $\mathrm{Fe}^{3+}$ ion; this oxidation occurs even more rapidly in the presence of EDTA. None of the following metal ions (all at $1 \mathrm{~mm}$ ) caused a significant relief of the inhibition of methanol oxidation by $0.2 \mathrm{~mm}$ EDTA: $\mathrm{Fe}^{2+}, \mathrm{Fe}^{3+}, \mathrm{Mg}^{2+}, \mathrm{Zn}^{2+}, \mathrm{Mn}^{2+}$ or $\mathrm{Ca}^{2+}$, when methanol-grown organism M 27 was used. These cations were added from a second side arm $20 \mathrm{~min}$. after the addition of the EDTA. 1,10-Phenanthroline $(2 \mathrm{mM})$ did not inhibit the oxidation of methanol or ethanol.

Phenylhydrazine and related compounds. The results of experiments with aldehyde-trapping agents summarized in Table 2 show that phenylhydrazine was a potent inhibitor of the oxidation of $\mathrm{C}_{1}$ compounds and of ethanol, whereas the oxidation of lactate, glyoxylate or endogenous substrate was unaffected. Table 3 shows that the most potent hydrazine derivative tested was $p$-nitrophenylhydrazine and this gave $50 \%$ inhibition at $1 \mu \mathrm{M}$.

\section{Evidence against catalase-mediated methanol oxidation in organism $M 27$}

Harrington \& Kallio (1960) suggested that Pseudomonas methanica (Iowa strain) oxidizes methanol by the peroxidative action of catalase with methanol as hydrogen donor. They showed that extracts of $P$. methanica (Iowa strain) catalysed methanol oxidation in a system containing added glucose and glucose oxidase to generate 
Table 2. Effect of phenylhydrazine on the oxidation of various substrates by methanol-grown organism M 27

Gas phase, air; temp., $30^{\circ}$; centre well, $0.2 \mathrm{ml}$. of $10 \%$ (w/v) $\mathrm{KOH}$; main compartment, $4 \mathrm{mg}$. dry wt. equiv. of

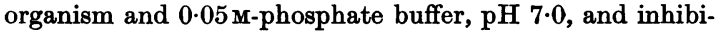
tor; side arm, substrate; total volume, $3 \mathrm{ml}$. Organisms and inhibitor were incubated together for $20 \mathrm{~min}$. at $30^{\circ}$ before addition of substrate from the side arm. $Q_{\mathbf{O}_{2}}$ values with the various substrates were corrected for endogenous oxygen uptake. (For $Q_{\mathrm{O}_{2}}$ values without inhibitor, see Table 1.) -, Not tested.

\begin{tabular}{lrrr} 
& \multicolumn{3}{c}{ Inhibition (\%) } \\
\cline { 2 - 4 } $\begin{array}{l}\text { Concn. of phenyl- } \\
\text { hydrazine }(\mu \mathrm{M})\end{array} \ldots \ldots$ \\
$\begin{array}{l}\text { Substrate for oxidation } \\
\text { ( } \mu \text { moles/3 ml.) }\end{array}$ & 4 & 10 & 100 \\
None & & & \\
Methanol (10) & -23 & - & 0 \\
Ethanol (20) & 9 & 37 & 100 \\
Formaldehyde (20) & 11 & 31 & 87 \\
Formate (160) & 6 & 32 & 41 \\
Lactate (16) & - & - & 0 \\
Glyoxylate (10) & - & - & 0
\end{tabular}

Table 3. Effect of various hydrazine derivatives and related compounds on methanol oxidation by methanolgrown organism $M 27$

Gas phase, air; temp., $30^{\circ}$; centre well, $0.2 \mathrm{ml}$. of $10 \%$ (w/v) $\mathrm{KOH}$; main compartment, $4 \mathrm{mg}$. dry wt. equiv. of

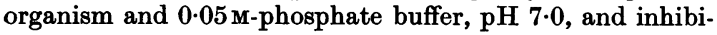
tor; side arm, substrate ( $40 \mu$ moles of methanol); total volume, $3 \mathrm{ml}$. Organisms and inhibitor were incubated together for $20 \mathrm{~min}$. at $30^{\circ}$ before addition of substrate from the side arm. $Q_{\mathbf{O}_{2}}$ of the control without inhibitor was - 97 (corrected for endogenous $Q_{\mathrm{O}_{2}}-11$ ).

$\quad$ Inhibitor (mM)
Hydrazine $(0 \cdot 01)$
Phenylhydrazine $(0 \cdot 01)$
$p$-Nitrophenylhydrazine $(0 \cdot 01)$
$p$-Nitrophenylhydrazine $(0 \cdot 001)$
$p$-Nitrophenylhydrazine $(0 \cdot 0001)$
2,4-Dinitrophenylhydrazine $(0 \cdot 01)$
Isonicotinic acid hydrazide $(0 \cdot 01)$
Aniline $(0 \cdot 01)$
Hydroxylamine $(0 \cdot 01)$
Hydroxylamine $(3 \cdot 3)$
Semicarbazide $(33)$

Inhibition

(\%)

15

50

100

50

10

6

0

0

0

74

0

hydrogen peroxide. No consideration was given to the necessity for a hydrogen peroxide-generating system in the whole organism and they presented no evidence that this mechanism operates in vivo. Evidence against a catalase-mediated methanol oxidation by organism M 27 was obtained from inhibitor studies with methanol-grown organisms; the results are summarized in Table 4. (Evidence for an alternative mechanism of methanol oxidation is presented by Anthony \& Zatman, 1964.) Catalase activity was completely abolished by sodium azide $(0.6 \mathrm{~mm})$ or hydroxylamine $(3.3 \mathrm{~mm})$, whereas methanol oxidation still continued at a significant rate. Conversely, methanol oxidation was completely inhibited by 5 mM-EDTA and the phenylhydrazines $(0.1 \mathrm{~mm})$, and neither had any effect on the catalase activity of the organisms.

\section{Formaldehyde accumulation during methanol oxidation by organism $M 27$}

When organisms were incubated with methanol in the presence of semicarbazide as trapping agent only about $8 \%$ of added methanol was trapped as formaldehyde during the time taken for the rate of oxygen uptake to decrease to the endogenous value. A corresponding decrease in total oxygen consumption in the presence of semicarbazide was observed as compared with a control without semicarbazide. Inclusion of formate $(30 \mu$ moles $)$ or lactate (16 $\mu$ moles) had no effect on the amount of formaldehyde formed, and calcium salts ( $16 \mu$ moles) gave a two- to five-fold increase. Ethanol ( $24 \mu$ moles) decreased the amount of accumulated formaldehyde to about one-third; this suggests a competitive inhibition of methanol oxidation by ethanol (see Zatman, 1946). Sodium borate $(0 \cdot 1 \mathrm{M})$ caused $95 \%$ inhibition of oxygen uptake with formaldehyde as substrate, but inhibited oxygen uptake with methanol by only $50 \%$. When $0.1 \mathrm{~m}$-borate replaced semicarbazide, some formaldehyde was found to accumulate.

\section{DISCUSSION}

All the organisms isolated with methanol or formate as sole carbon and energy source during this work were strictly aerobic, Gram-negative straight rods, motile by single polar flagella. These characteristics suggest that they are members of the family Pseudomonadaceae (Bergey's Manual, 1957). All the organisms isolated contained intracellular vacuoles of lipid and produced a red pigment which was insoluble in water. All grew on a range of substrates as sole source of carbon and energy. The similarity of these organisms to those listed by Peel \& Quayle (1961) suggests that they should be placed in the same genus, and, following these workers and Dworkin \& Foster (1956), we suggest that they belong to the genus Pseudomonas.

The results of investigations on the oxidative metabolism of Pseudomonas sp. M 27 indicate that enzymes are present which will catalyse all the steps in the pathway:

$$
\mathrm{CH}_{3} \cdot \mathrm{OH} \rightarrow \mathrm{H} \cdot \mathrm{CHO} \rightarrow \mathrm{H} \cdot \mathrm{CO}_{2} \mathrm{H} \rightarrow \mathrm{CO}_{2}+\mathrm{H}_{2} \mathrm{O}
$$




\section{Table 4. Effect of inhibitors on methanol oxidation and on catalase activity of organism $M 27$}

Gas phase, air; temp., $30^{\circ}$; centre well, $0 \cdot 2 \mathrm{ml}$. of $10 \%$ (w/v) KOH; main compartment, 0.05 M-phosphate buffer, $\mathrm{pH} 7 \cdot 0$, and $0 \cdot 43-4 \cdot 3 \mathrm{mg}$. dry wt. equiv. of methanolgrown organisms and inhibitor; side arm, substrate $(40 \mu$ moles of methanol or $36 \mu$ moles of $\mathrm{H}_{2} \mathrm{O}_{2}$ ); total volume, $3 \mathrm{ml}$. Control $Q_{\mathrm{O}_{2}}$ values obtained without inhibitor were -98 for methanol oxidation (corrected for endogenous $Q_{\mathrm{O}_{2}}-10$ ) and +10000 for catalase activity.

\section{Inhibitor (mM)}

EDTA (5)

Phenylhydrazine (0.1)

$p$-Nitrophenylhydrazine $(0 \cdot 1)$

Hydroxylamine (3.3)

Sodium azide (0.02)

Sodium azide $(0 \cdot 1)$

Sodium azide $(0 \cdot 6)$

Sodium azide (4)

\begin{tabular}{cc} 
Methanol & \multicolumn{2}{c}{ Inhibition (\%) } \\
oxidation & $\begin{array}{c}\text { Catalase } \\
\text { activity }\end{array}$ \\
100 & 0 \\
100 & 0 \\
100 & 0 \\
69 & 100 \\
10 & 84 \\
10 & 93 \\
50 & 100 \\
65 & 100
\end{tabular}

There is some evidence that formaldehyde is an intermediate during methanol oxidation, although the low yields suggest that it may occur in a bound form. The inhibition of formaldehyde accumulation by ethanol and the similarity in sensitivity of methanol oxidation and ethanol oxidation to EDTA and phenylhydrazine suggest that the enzyme systems for the oxidation of methanol and ethanol are related if not identical.

One might reasonably speculate that a folic acid coenzyme is involved in the metabolism of methanol by Pseudomonas sp. M 27 and the inhibition by EDTA of methanol oxidation is perhaps significant in this connexion. This inhibition does not appear to be due to removal of necessary cations by chelation. It is of interest that the ethylenediamine structure is the active centre of folic acid derivatives in their capacity as $\mathrm{C}_{1}$ carriers and substituted ethylenediamines are known to be competitive inhibitors of certain enzymes dependent on folic acid (Jaenicke, 1961).

The inhibition of oxidation of $\mathrm{C}_{1}$ compounds and ethanol by $0.1 \mathrm{~mm}$-phenylhydrazine suggests that there is a common factor which operates in the oxidation of these compounds; this might be a component of the hydrogen-transport system or a $\mathrm{C}_{1}$ carrier, e.g. a folic acid derivative. Perhaps the hydrazines inhibit the oxidation of $\mathrm{C}_{1}$ compounds by reaction with the carbonyl group of an essential cofactor. This seems unlikely, however, since a high concentration of semicarbazide, which is also a carbonyl reagent, has no effect. An alternative mode of action of the hydrazines might result from their activity as reducing agents. However, hydrazine is a more powerful reducing agent than $p$-nitrophenylhydrazine, but is a much less active inhibitor.

\section{SUMMARY}

1. An organism capable of growth on certain $C_{1}$ compounds as sole source of carbon and energy has been isolated from soil and has been designated Pseudomonas sp. M 27. It is a Gram-negative rod, motile by a single polar flagellum, forms sudanophilic vacuoles and produces a water-insoluble pink or red pigment under all conditions of growth.

2. Pseudomonas sp. M 27 can grow aerobically with methanol, methylamine or formate as sole source of carbon and energy. It cannot grow with methane or formaldehyde, but grows well on ethanol, lactate, acetate or succinate.

3. The pigment from Pseudomonas sp. M 27, which appears to be an unsaturated carotenoid, has been extracted in several organic solvents; the absorption spectra of the extracts are similar to those of related organisms.

4. The effect of several inhibitors, including cyanide, hypophosphite, chelating agents and various hydrazines, on the oxidative metabolism of washed suspensions of Pseudomonas sp. M 27 was investigated manometrically. EDTA and phenylhydrazines are potent inhibitors of the oxidation of methanol and ethanol by Pseudomonas sp. M 27. Methanol oxidation is inhibited $50 \%$ by $1 \mu \mathrm{M}-p$ nitrophenylhydrazine.

5. Evidence is presented against a catalasemediated methanol oxidation by washed suspensions of Pseudomonas sp. M 27.

We thank the University of Reading for the award of a Research Scholarship to C.A.

\section{REFERENCES}

Anthony, C. \& Zatman, L. J. (1963). J. gen. Microbiol. 31, $3 \mathbf{P}$.

Anthony, C. \& Zatman, L. J. (1964). Biochem. J. 92, 614. Bachrach, U. (1957). Biochem. J. 66, 59.

Bergey's Manual of Determinative Bacteriology, 7th ed. (1957). Ed. by Breed, R. S., Murray, E. G. D. \& Smith, N. R. London: Baillière, Tindall and Cox.

Burdon, K. L. (1946). J. Bact. 53, 65.

Campbell, L. L. (1954). J. Bact. 68, 598.

Dawson, R. M. C., Elliott, D. C., Elliott, W. H. \& Jones, K. M. (1959). Data for Biochemical Research. Oxford: Clarendon Press.

Dworkin, M. \& Foster, J. W. (1956). J. Bact. 72, 646.

Harrington, A. A. \& Kallio, R. E. (1960). Canad. J. Microbiol. 6, 1.

Jaenicke, L. (1961). In The Mechanism of Action of Water soluble Vitamins, p. 49. Ed. by de Reuck, A. V.S. \& O'Connor, M. London: J. and A. Churchill Ltd.

Kaneda, T. \& Roxburgh, J. M. (1959a). Canad. J. Micro. biol. 5, 87.

Kaneda, T. \& Roxburgh, J. M. (1959b). Canad. J. Microbiol. 5, 187.

Karrer, P. \& Jucker, E. (1950). Carotenoids. London: Elsevier Publishing Co. 
Kornberg, H. L. \& Sadler, J. R. (1960). Nature, Lond., 185, 153.

Large, P. J. \& Quayle, J. R. (1963). Biochem. J. 87, 386.

Leadbetter, E. \& Foster, J. W. (1958). Arch. Mikrobiol. 30, 91.

MacFadyen, D. A. (1945). J. biol. Chem. 158, 107.

Peel, D. \& Quayle, J. R. (1961). Biochem. J. 81, 465.

Quayle, J. R. (1961). Annu. Rev. Microbiol. 15, 119.

Rhodes, M. E. (1958). J. gen. Microbiol. 18, 639.
Takamiya, A. (1942). Acta phytochim. 13, 1.

Takamiya, A. (1943). Acta phytochim. 13, 193.

Takamiya, A. (1953). J. Biochem., Tokyo, 40, 415.

Treadwell, F. P. \& Hall, W. T. (1935). Analytical Chemistry, vol. 2, p. 369. New York: John Wiley and Sons, Inc.

Umbreit, W. W., Burris, R. M. \& Stauffer, J. F. (1957). Manometric Techniques. Minneapolis: Burgess Publishing Co.

Zatman, L. J. (1946). Biochem. J. 40, lxvii.

Biochem. J. (1964), 92, 614

\title{
The Microbial Oxidation of Methanol
}

\section{THE METHANOL-OXIDIZING ENZYME OF PSEUDOMONAS SP. M 27}

\author{
BY C. ANTHONY AND L. J. ZATMAN \\ Department of Microbiology, University of Reading
}

(Received 21 November 1963)

The preceding paper (Anthony \& Zatman, 1964) described the isolation and properties of Pseudomonas sp. M 27, an organism capable of growth on methanol, methylamine or formate as sole source of carbon and energy. The pathway of methanol assimilation in a similar organism, Pseudomonas AM 1 (Peel \& Quayle, 1961), has been investigated and data on several of the enzymes involved have been published (Large, Peel \& Quayle, 1962 ; Large \& Quayle, 1963). However, apart from catalase, no enzyme which catalyses the first essential oxidative step in methanol metabolism has been described; Anthony \& Zatman (1964) showed that catalase was not responsible for methanol oxidation in Pseudomonas sp. M27. All known alcohol dehydrogenases require NAD or NADP as coenzyme and none shows appreciable activity with methanol as substrate (Negelein \& Wulff, 1937; Racker, 1950; Barron \& Levine, 1952; Stafford \& Vennesland, 1953; DeMoss, 1954; Bonnichsen \& Brink, 1955; Atkinson \& Serat, 1960; Azoulay \& Heydeman, 1963). The present paper describes an enzyme system in Pseudomonas sp. M27 which catalyses methanol oxidation and which is independent of nicotinamide nucleotide coenzymes. A preliminary report of part of this work has been presented to The Society for General Microbiology (Anthony \& Zatman, 1963).

\section{MATERIALS AND METHODS}

Cytochrome $c$ and $N$-methylphenazonium methosulphate (phenazine methosulphate) were obtained from L. Light and Co. Ltd. The latter was stored at $2^{\circ}$ in the solid state and $1 \%(\mathrm{w} / \mathrm{v})$ solutions were stored frozen $\left(-22^{\circ}\right)$ in the dark. When thawed out for use solutions were still kept in the dark as far as possible. 2,6-Dichlorophenolindophenol was obtained from British Drug Houses Ltd. It was dissolved in water, left overnight and any insoluble material filtered off. It was standardized colorimetrically at $600 \mathrm{~m} \mu$; the molar extinction coefficient at $600 \mathrm{~m} \mu$ was taken to be $1.91 \times 10^{7} \mathrm{~cm}^{2} \mathrm{~mole}^{-1}$ (Basford \& Huennekens, 1955). NAD and NADP were obtained from Boehringer und Soehne, Mannheim, Germany. NAD nucleosidase of Neurospora crassa (500 units/ml.) was prepared according to the method of Kaplan (1955) and crystalline alcohol dehydrogenase of baker's yeast according to the method of Racker (1955). Buffers were prepared according to the data of Dawson, Elliott, Elliott \& Jones (1959).

Spectrophotometry. All spectrophotometric measurements were made with a Unicam SP. 500 spectrophotometer and cuvettes of $10 \mathrm{~mm}$. light-path.

Preparation of sonic extracts. Methanol-grown organisms were grown and harvested as described by Anthony \& Zatman (1964), and a suspension of $1.5 \mathrm{~g}$. wet wt. of organisms $/ 10 \mathrm{ml}$. of $0.05 \mathrm{M}$-phosphate buffer, pH $7 \cdot 0$, was prepared. This was exposed for 10-15 min. to ultrasonic oscillation at $20 \mathrm{kcyc}$./sec. in a $60 \mathrm{w}$ MSE-Mullard ultrasonic disintegrator with pure titanium probes (diameter $19 \mathrm{~mm}$.), the vessel containing the suspension being immersed in an ice bath. The suspension was treated in $10 \mathrm{ml}$. quantities in a small glass vessel whose diameter was hardly more than that of the probe, which was dipped just below the surface of the suspension. This treatment was sufficient to break most of the organisms, as judged by phase-contrast microscopy. After treatment the suspension was centrifuged at $35000 \mathrm{~g}$ for $1 \mathrm{hr}$. at $0^{\circ}$ and the pink almost clear supernatant liquid collected; this is referred to as the crude sonic extract.

Protein estimation. Two methods were used: the method of Lowry, Rosebrough, Farr \& Randall (1951) and the spectrophotometric method of Warburg \& Christian (1941). The procedures were those of DeMoss \& Bard (1957). Standard curves were prepared from crystallized bovine plasma albumin obtained from Armour Pharmaceutical Co. Ltd. 